\title{
THE EFFECTS OF REMOVAL OF JUNIPERUS VIRGINIANA L. TREES AND LITTER FROM A CENTRAL OKLAHOMA GRASSLAND
}

\author{
Jerad S. Linneman ${ }^{1}$ \\ Matthew S. Allen ${ }^{2}$ \\ Michael W. Palmer ${ }^{2}$ \\ mike.palmer@okstate.edu
}

\author{
${ }^{1}$ USDA \\ Animal \& Plant Health Inspection Service \\ 4700 River Rd., Unit 153, 5D-06G \\ Riverdale, MD 20737-1228 \\ ${ }^{2}$ Oklahoma State University \\ Department of Botany \\ 301 Physical Sciences \\ Stillwater, OK 74078-3013
}

Keywords: biodiversity, experiment, invasion, ordination

\begin{abstract}
We studied species composition after Juniperus virginiana tree and litter removal in a central Oklahoma grassland. Tree removal had the most significant effect on stems per quadrat and vegetation cover. Litter removal effects were not as strong. However, stems per quadrat and vegetation cover in litter removal treatments were higher than in litter intact treatments. Species richness increased for all treatments in the first year post-treatment, after which species richness declined at every sampling period and in every treatment for the duration of the study. Absolute cover of typical prairie species increased in the cut with no litter treatment whereas cover of woody forest species increased in the no cut with no litter treatment. We suggest that even without prescribed fire, redcedar tree removal may result in a return of prairie vegetation. However, additional efforts besides tree removal may be required to restore some invaded grasslands.
\end{abstract}

\section{INTRODUCTION}

For the last several decades, there has been a growing interest in management techniques required to maintain and/or restore vegetation. The two most common problems faced in grassland restoration are habitat destruction and the loss of native species diversity due to the encroachment of woody species. Concerns about decreased diversity and the invasion of exotic woody species have spurred extensive study throughout the world including Argentina (Ghersa et al. 2002), Australia (Costello et al. 2000, Whiteman and Brown 1998), Canada (Peltzer and Köchy 2001), French Prealps (Barbaro et al. 2001), South Africa (Holmes et al. 2000, Holmes and Marais 2000) and the United States (Petranka and
McPherson 1979, Callaway and Aschehoug 2000, Fitch et al. 2001, Briggs et al. 2002b, van Els et al. 2010).

In the United States, two examples of fire adapted vegetation types that have received much attention regarding restoration are the longleaf pine sandhill vegetation of northwestern Florida (Kush et al. 1999, Provencher et al. 2000, Provencher et al. 2001) and the tallgrass prairie of the eastern Great Plains (Axmann and Knapp 1993, Briggs et al. 2002a, Briggs et al. 2002b). In both instances the elimination of fire has caused a decrease in species richness and facilitated their conversion into forests. Tallgrass prairie researchers have suggested that reductions in abundance and altered community composition are related to a 
multitude of environmental factors associated with woody invasion. Examples of such altered environmental factors include soil moisture (Engle et al. 1987, Facelli and Pickett 1991b), solar radiation (Smith and Stubbendieck 1990, Facelli and Pickett 1991 a \& b) and soil temperature (Weaver and Rowland 1952, Hulbert 1969). In addition, leaf litter from woody species may alter grassland litter dynamics (Facelli and Pickett 1991b).

Within the tallgrass prairie region, eastern redcedar (Juniperus virginiana L.) has increased dramatically, converting millions of hectares of grassland to woodland or closed canopy forest (Schmidt and Leatherberry 1995, Briggs et al. 2002a). Redcedar invasion is not restricted to impacted or degraded sites and exhibits high survivorship in diverse native grasslands (Ganguli et al. 2008). Typical control methods include mechanical felling via chainsaws, large cutting machinery, or cabling and prescribed fire. Although felling and prescribed fire are effective in reducing redcedar abundance in prairies, the continuous application of this management technique has left a significant gap in our understanding about the role redcedar litter plays in tallgrass prairie restoration. In particular, we do not understand the role of the overstory tree versus the leaf litter in determining species composition.

We conducted this study to disentangle the effects of redcedar overstory canopy and accumulated litter on prairie species richness and composition. Elucidating these effects will allow for a more informed approach to redcedar removal and prairie restorations.

\section{METHODS}

\section{Study Site}

We conducted this experiment at the James K. McPherson Botanical Preserve located $16 \mathrm{~km}$ west of Stillwater, Oklahoma (36 $\left.06^{\circ} 00^{\prime \prime} \mathrm{N}, 97^{\circ} 12^{\prime} 30^{\prime \prime} \mathrm{W}\right)$. After a brief period of row crop agriculture, the site was converted into pastureland and grazed until the 1960's. Oklahoma State University (OSU) purchased the land and managerial control was turned over to the Department of Botany. In 1995, the Department of Botany introduced a burning regime, consisting of a three to five year return interval, to the northwestern half of the preserve with the goal of stimulating the return of a native tallgrass prairie community.

\section{Tree Selection and Classification}

We selected 47 potential study trees based on several criteria including tree isolation, minimization of surrounding tree effects, the existence of an intact litter layer underneath the tree, and tree size. We recorded canopy diameter in the northsouth and east-west direction, height, stem diameter at both $10 \mathrm{~cm}$ and diameter-atbreast-height (DBH), and gender. For those trees with multiple stems, we recorded separate diameter measurements for each primary stem, which we later converted into basal area $(\mathrm{BA})$ at $10 \mathrm{~cm}$ and $\mathrm{DBH}$, respectively. We randomly assigned all trees into two groups (cut and no cut); ten study trees were then randomly selected from each group.

\section{Sampling Design}

Sampling design was based on a two by two factorial design of tree removal and litter removal. Underneath each study tree, we positioned two $50 \mathrm{~cm} \times 50 \mathrm{~cm}$ quadrats so that each quadrat was completely under the canopy of the overstory redcedar. In addition, we positioned the two quadrats in such a way to maintain homogenous litter cover between quadrats and to minimize inter-quadrat variation in vegetation. After permanently marking each quadrat, we randomly assigned a litter removal treatment to one of the two quadrats under each tree. We conducted an initial vegetation sampling in May 2001, prior to treatment application. 
All subsequent sampling occurred biennially in May and September of 2002 - 2003.

Sampling of species composition consisted of identifying each plant species rooted inside the quadrat and estimating its percent cover to the nearest percent for any cover less than $5 \%$ and to the nearest $5 \%$ for any cover over $5 \%$. We marked unknown species for later identification. Species nomenclature and code symbols follow that of the USDA PLANTS database (USDA 2004). In addition, at several locations within this paper we refer to the response of $J$. virginiana redcedar seedlings and not the study tree or any of its structures.

\section{Experimental Treatments}

The tree removal treatment was applied using a chainsaw and pruning shears between 17 and 19 May, 2001. We removed crowns and branches from the top down, with the aid of rigging equipment, to minimize the amount of disturbance to the litter layer and vegetation in the quadrats. We removed litter from litter removal quadrats by hand, taking care to minimize disturbance to vegetation. However, plants that had germinated in the litter layer and had not reached the soil surface were removed along with the litter during the initial treatment. The litter removal treatment was applied between 21 and 24 May, 2001. Treatment acronyms for tree and litter removal are: cut with no litter $(\mathrm{CN})$, cut with litter (CL), no cut with no litter $(\mathrm{NN})$, and no cut with litter $(\mathrm{NL})$; i.e. the control.

At each post-treatment sampling, we removed newly accumulated litter from the litter removal quadrats after observing vegetation. On a few occasions we removed branches from surrounding trees that started to grow over the tree removal quadrats.

\section{Statistical Analyses}

Statistical analysis included the use of both ANOVA and ordination techniques.
We performed repeated measures ANOVA using PROC MIXED for each environmental variable recorded using SAS (Version 8). For each environmental variable, initial (pre-treatment) observations were used as a baseline for all subsequent samplings (post-treatment). Preliminary analyses included tree gender as an explanatory variable. However, because gender showed no significant main or interaction effects, we removed gender and re-ran all ANOVAs.

We analyzed compositional data using direct gradient analysis. Direct gradient analysis uses species data and directly relates it to measured environmental variables, in this case dummy variables representing the treatments. We selected partial Redundancy Analysis (pRDA) because it is generally considered more appropriate in short-term experimental studies where species responses are believed to be linear and over relatively short gradients. All ordinations were conducted using CANOCO FOR WINDOWS 4.5 (ter Braak and Šmilauer 2002) on absolute cover of each species within a sample.

We developed a priori hypotheses about the potential affect of treatment application on species cover. We hypothesized that tree removal and litter removal would have a positive effect on stems per quadrat, vegetation cover and species richness. In addition, the combination of tree removal with litter removal, conditions most similar to open prairie $(\mathrm{CN})$, would have the largest effect; whereas, the combination of no tree removal and no litter removal, the control condition (NL), would have no effect or the least positive effect on species. We have not included any correction factors for statistical problems associated with multiple comparisons (Legendre and Legendre 1998, Hallgren et al. 1999). 


\section{RESULTS}

\section{Density and Richness}

There were significant differences in stem density $(p<0.001)$ between all quadrats prior to treatment application. However, the difference between the means of the densest and sparsest treatments was only 2.5 stems per quadrat. Both the cut with litter (CL) and cut with no litter $(\mathrm{CN})$ treatments had the lowest stems per quadrat prior to treatment application. Stem density increased for all treatments except no cut with litter (NL) treatment by the second sampling. This increase was roughly 2-2.5 fold thus resulting in an increase of 10-13 stems per treatment (Figure 1). Significant differences $(p=0.0052)$ in density between NL \& NN (no cut-no litter) only occurred in May 2002. On the other hand, there were significant differences in stems density between litter treatments within the cut treatment, CL and CN, in September 2002 $(p=0.0366)$ and 2003 ( $p=0.0483)$. The cut treatment had a much more pronounced effect on density regardless of litter treatment. In September and May 2002 2003, there were significant differences between both $\mathrm{CN}$ and NN ( $p=0.006,0.004$, 0.001 respectively) and CL and NL ( $p=0.0052,0.003,0.0159$ respectively).

As with density, there were significant differences in initial species richness $(p<0.001)$ between all quadrats prior to treatment application. Again, the magnitude of the mean difference was quite small, fewer than 1.0 species per treatment. Additionally, the CL and $\mathrm{CN}$ treatments again had the lowest richness. The increase in species richness by the second sampling was not as dramatic as that observed in stems per quadrat by the same sampling. Generally increases in mean species richness were in the order of 0.4-1.25 species per quadrat (Figure 2). Significant differences in species richness between NL and NN only occurred in September 2002 ( $p=0.0244)$; however May 2002 was marginally insignificant ( $p=0.0533)$. Conversely, significant differences in species richness between CL and CN occurred in both May $2002(p=0.0381)$ and September 2002 $(p=0.0026)$. The cut treatment had a slightly weaker influence on species richness as compared to stems per quadrat. Significant differences in species richness were observed between $\mathrm{CN}$ and $\mathrm{NN}$ in September $2002(p=0.0055)$ and 2004 $(p=0.0007)$. Significant differences in species richness were also observed between CL and NL in September $2002(p=0.0457)$ and September 2003 ( $p=0.0358)$.

\section{Vegetation Cover}

There was no significant difference in total vegetation cover prior to treatment application. There was a substantial increase in total cover through samplings two and three in both the CL and CN treatments (Figure 3). This increase in total cover was in the order of $8.75-11.25 \%$. On the other hand, total cover in both the NN and NL treatments only increased by $\sim 2 \%$. No significant differences in total cover were observed between the NL and NN treatments at any sampling. On the other hand, there was a significant difference between the CL and CN treatments in September 2003 ( $p=0.0024)$. Although litter removal did not have a major effect on total cover, tree removal did. Significant differences between $\mathrm{CN}$ and $\mathrm{NN}$ were observed in September and May 2002-2003 ( $p=0.001,0.0023,<0.001$ respectively). In addition, significant differences between CL and NL were also observed in September and May 2002-2003 ( $p=0.0071,0.0075$, 0.0318 respectively).

Unlike total vegetation cover, there were significant differences $(p<0.001)$ in initial mean forb cover between treatments; however these differences were only $0.125 \%$. Forb cover in both of the cut treatments, CL and CN, increased over the duration of the study although both no cut treatments, NL and NN, were relatively 
static throughout the study (Figure 4). There were no significant differences in forb cover for NL or NN treatments at any time, whereas a significance difference between $\mathrm{CL}$ and $\mathrm{CN}$ only occurred in September 2002 ( $p=0.0056)$. The tree removal treatment yielded a significant difference between CN and NN in May 2002 $(p<0.0001)$ and September $2002(p=0.0486)$, whereas a significant difference between CL and NL occurred only in May 2003 $(p=0.0131)$.

Graminoid cover responded similarly to forb cover with significant differences in initial mean graminoid cover between treatments $(p=0.0164)$. Once again, the differences between treatments were small $(0.15 \%)$. Graminoid cover increased over the first post-treatment sampling for all treatments (Figure 5). Graminoid cover was not significantly affected by litter in NL or NN treatments. However, litter had a significant effect in September 2003 $(p=0.0012)$ in the CL and CN treatment. The tree removal treatment had a stronger affect with significant differences in graminoid cover between $\mathrm{CN}$ and $\mathrm{NN}$ in September and May 2002-2003 $(p=0.0253$, $0.0092,<0.0001$ respectively) and between CL and NL in September 2002 ( $p=0.0133$ ). Marginal insignificance was also observed between CL and NL in May, 2003 $(p=0.052)$.

Significant differences in woody cover $(p=0.0197)$ were also present at the onset of this study. However, differences in mean woody cover between treatments were once again small $(0.15 \%)$. Woody cover increased in all treatments over the duration of this study although these increases were only in the $0.5-2.0 \%$ range (Figure 6 ). In fact, no significant differences were found between any combination of litter removal and/or tree removal treatments at any sampling.

\section{Direct Gradient Analysis}

Partial Redundancy Analysis (pRDA) was conducted to test a priori hypotheses regarding the effects of tree removal, litter removal and their interaction at each sampling. Results of pRDA only showed significant differences in absolute species cover between litter removal treatments in May, 2002 and September, $2002(p<0.001)$. Conversely, pRDA showed significant differences $(\phi<0.001)$ in absolute species cover between tree removal treatments at every post-treatment sampling period. The litter removal with tree removal interaction effect was only significant in September 2002 ( $p=0.029)$. Therefore, it appears that tree removal does have a stronger effect on species composition over time than litter removal. When treatment centroids by sampling period are plotted in ordination space three items become apparent: First, tree removal results in an increased magnitude of movement of treatment centroids over time (Figure 7 a, b). Second, litter removal also results in an increased magnitude of movement of treatment centroids over time (see Figure $7 \mathrm{a}, \mathrm{b}$ ). Finally, the overall amount of compositional change of cut treatments was greater than litter removal treatments.

A pRDA scatter plot of absolute species cover, treatment centroids and passive environmental variables based on all posttreatment samplings is displayed in Figure 8. The four dummy treatment variables accounted for $5.4 \%$ of the total explained species variance. Although woody cover was not significantly affected by tree removal or litter removal treatments at any sampling, woody forest species such as Cercis canadensis, Celtis occidentalis, Parthenocissus quinquefolia, Quercus stellata, Juniperus virginiana seedlings, and Ulmus rubra all dominated the no cut treatments with a slightly higher cover in the litter treatment (NL). Alternatively, grasses typical of the open prairie such as Tridens flavus, Eragrostis 
spectabilis, Dicanthelium oligosanthes, Sorghastrum nutans, Botbriochloa saccharoides, and Sporobolus compositus dominated the tree removal treatments. In addition, each one of these graminoids (with the exception of T. flavus) also had higher absolute cover in the litter removal treatment (CL). Sedges such as Carex festucacea and C. bushii both dominated the NN treatment. On the other hand, forb species typically associated with pastures such as Ambrosia sp., A. psilostachya, Amphiachyris dracunculoides, Acalypha gracilens, and Croton monanthogynus dominated the $\mathrm{CN}$ treatment.

\section{DISCUSSION}

Increases in stem density and species richness were expected as a result of litter removal and tree removal treatments. Our results are similar to those of Monk and Gabrielson (1985) who observed a stronger influence of overstory cover compared to litter cover on old field vegetation. For all manipulated quadrats (CL, $\mathrm{CN}$, and $\mathrm{NN}$ ) increased stems per quadrat is more likely to be due to increased perennial graminoid stems than woody or forb stems.

Reductions in stems per quadrat in NL and NN treatments after September 2002 are likely the result of continued overstory tree presence and its associated reductions in solar radiation. Studies by Monk and Gabrielson (1985), Yager and Smeins (1999), and Joy and Young (2002) have all suggested that reductions in light similar to those observed in this study resulted in significant decreases in plant density and cover. On the other hand, we believe that reductions in stems per quadrat in September 2003 for CL and only the slight increase for $\mathrm{CN}$ were caused by relatively little precipitation received in $2002-2003$. Total precipitation recorded at the Marena Mesonet Station, located approximately $4 \mathrm{~km}$ from the study site, was $63.0 \mathrm{~cm}$ from October 2002 to September 2003. This precipitation total is only $64-69 \%$ of annual precipitation for the site of $91.4-99.1 \mathrm{~cm}$ (Oklahoma Mesonet, Oklahoma Climatological Survey).

By comparison, the decreases in species richness over the course of this study suggest relatively little recruitment of new species occurred regardless of treatment. Provencher et al. (2000) found that species richness also decreased after the application of felling and slash burning in Florida's sandhill vegetation. However, Provencher et al. (2000) observed an increase in species richness two years after treatment application. Results from pRDA (see Figure 8) suggest a transition from pretreatment species composition dominated by mesic or forest species to post-treatment tallgrass prairie species. It is possible that during this transition, forest species were lost faster than prairie species were added; therefore, we observe a decrease in species richness. However, the majority of species present in each treatment's cumulative species pool were, on average, not present in each quadrat. Generally only $10-20 \%$ of each treatment's cumulative species pool was observed in each quadrat (see Figure 2). It should be noted that species richness may be strongly linked to density (i.e. rarefaction effect) and thus the richness-per-quadrat should not be interpreted independently of stem counts (Palmer et al. 2000). This suggests that given more time species richness may increase as these rare species become more universally distributed into cut quadrats.

Linneman and Palmer (2006) suggested that species composition underneath redcedar trees may be a random subset of the species from the surrounding matrix. The results from this study suggest that this subset of species is nonrandom and comprised of two main types. The first group appears to be remnant prairie grasses, and the second is disturbance-tolerant forbs. The absolute cover of almost all graminoid species increased as a result of tree removal. Of particular interest is that the most 
abundant graminoid species were native tallgrass prairie species such as Sorghastrum nutans and Sporobolus compositus. Conversely, the positive response of disturbance favoring forb species like Amphiachyris dracunculoides, Ambrosia psilostachya and Croton monanthogynus may lead to further reductions in species richness if they become dominant. Several researchers, including Clary (1971), Clary and Jameson (1981), Brockway et al. (1998), and Provencher (2000), have all observed increases in graminoid and forb cover following overstory tree removal. In this study, annual species increased in cut treatments; however, few annuals dominated cover in any treatment. Although the increase of disturbance-tolerant forbs may be inhibitive in the short term, the observed increases in absolute cover of native tallgrass prairie species suggest that even without subsequent prescribed fire treatments, community composition may return to its pre-invasion condition with time.

The long-term effects of eastern redcedar in grasslands are unclear. The results from this study suggest the continued presence of eastern redcedar in grasslands may (1) facilitate the forestation of grasslands or at least (2) continue to reduce the tallgrass prairie species pool in invaded grasslands. Briggs et al. (2002a) determined that species present in the prairie were not consistently different from those found in a closed canopy redcedar forest. However, both this study and Linneman and Palmer (2006) show an apparent shift in community composition away from tallgrass prairie species toward forest tree species such as Cercis canadensis, Celtis occidentalis, Juniperus virginiana, Quercus stellata and Ulmus rubra. These same tree species frequently occur under redcedar canopies in nearby Cross Timbers forest environments as well (van Els et al. 2010) and, it should be noted, the cedars studied here were in relatively close proximity to Cross Timbers stands. Additionally, it is possible that the dynamics of cedar invasion may differ in old fields (studied here) from those in previously undisturbed prairie.

Although complete extirpation of native tallgrass prairie species is not likely in the short term, areas with extensive invasion and subsequent tree removal may require seeding of prairie species to encourage the return of characteristic prairie vegetation. This will inevitably increase the cost of restoration beyond the already high cost of tree removal (Bidwell et al. 2002). Areas with less than $75 \%$ cover of redcedar, however, have greater potential for recovery, as most tallgrass prairie species persist in inter-tree spaces until this point (Limb et al. 2010).

Continued invasion by eastern redcedar in the Great Plains has serious implications not only for the existence of native grasslands but also for biodiversity and potential future restorations. As shown here, removal of redcedar, even in the absence of subsequent prescribed fire, has the potential to increase the number of stems per quadrat and increase species richness for several years post-treatment. Litter removal, either by mechanical means or prescribed fire, should further benefit and accelerate the return of tallgrass prairie vegetation. Without tree removal, these grasslands will continue to lose native prairie species in favor of mesic and/or forest species. In the absence of broad-scale control efforts, redcedar will continue to fragment and replace native grasslands, perhaps to the extent that future prairie restoration efforts may require seed inputs beyond what is available from surrounding sources via natural dispersal.

\section{ACKNOWLEDGMENTS}

We thank Sam Fuhlendorf for his editorial comments. In addition, Jared Laufenberg aided with tree removal. Mark Payton's help with SAS analyses and programming was greatly appreciated. The 
Payne County Audubon Society and the James K. McPherson Fund, administered by the Department of Botany at Oklahoma State University, provided funding for this study.

\section{LITERATURE CITED}

Axmann, B. D. and A. K. Knapp. 1993. Water relations of Juniperus virginiana and Andropogon gerardii in an unburned tallgrass prairie watershed. Southwestern Naturalist 38:325-330.

Barbaro, L., T. Dutoit and P. Cozic. 2001. A six-year experimental restoration of biodiversity by shrub-clearing and grazing in calcareous grasslands of the French Prealps. Biodiversity Conservation 10:119-135.

Bidwell, T. G., D. M. Engle, R. E. Masters, and J. R. Weir. 2002. Fire effects in Oklahoma. Oklahoma Cooperative Extension Service. F-2877.

Briggs, J. M., G. A. Hoch and L. C. Johnson. 2002a. Assessing the rate, mechanisms, and consequences of the conversion of tallgrass prairie to Juniperus virginiana forest. Ecosystems 5:578-586.

Briggs, J. M., A. K. Knapp, and B. L. Brock. 2002b. Expansion of woody plants in tallgrass prairie: A fifteen-year study of fire and fire-grazing interactions. American Midlands Naturalist 147:287294.

Brockway, D. G., K. W. Poutcalt, and R. N. Wilkins. 1998. Restoring longleaf pine wiregrass ecosystems: Plant cover, diversity and biomass following low-rate hexazinone application on Florida sandhills. Forest Ecology Management 103:159-175.

Callaway, R. M. and E. T. Aschehoug. 2000. Invasive plants versus their new and old neighbors: A mechanism for exotic invasion. Science 290:521-523.

Clary, W. P. 1971. Effects of Utah juniper removal on herbage yields from
Springerville soils. Journal of Range Management 24:373-378.

Clary, W. P. and D. A. Jameson. 1981. Herbage production following tree and shrub removal in the pinyon-juniper type of Arizona. Journal of Range Management 34:109-113.

Costello, D. A., I. D. Lunt, and J. E. Williams. 2000. Effects of the invasion by the indigenous shrub Acacia sophorae on plant composition of costal grasslands in south-eastern Australia. Biological Conservation 96:113-121.

Engle, D. M., J. F. Stritzke, and P. L. Claypool. 1987. Herbage standing crop around eastern red cedar trees. Journal of Range Management 40:237-239.

Facelli, J. M. and S. T. A. Pickett. 1991a. Plant litter: Light interception and effects on an old-field plant community. Ecology 72:1024-1031.

Facelli, J. M. and S. T. A. Pickett. 1991b. Plant litter: Its dynamics and effects on plant community structure. Botanical Review 57:1-32.

Fitch, H. S., P. von Achen and A. F. Echelle. 2001. A half century of forest invasion on a natural area in northeastern Kansas. Transactions of the Kansas Academy of Science 104:1-17.

Ganguli, A. C., D. M. Engle, P. M. Mayer, and E. C. Hellgren. 2008. Plant community diversity and composition provide little resistance to Juniperus encroachment. Botany 86:1416-1426.

Ghersa, C. M., D. O. Ferranro, M. Omacini, M. A. Martinez-Ghersa, S. Pereaman, E. H. Satorre, and A. Soriano. 2002. Farm and landscape level variables as indicators of sustainable land-use in the Argentine Inland-Pampa. Agricultural Ecosystems Environment 93:279-293.

Hallgren, E., M. W. Palmer, and P. Milberg. 1999. Data diving with cross-validation: an investigation of broad-scale gradients in Swedish weed communities. Journal of Ecology 87:1-16. 
Holmes, P. M. and C. Marais. 2000. Impacts of alien plant clearance on vegetation in the mountain catchments of the Western Cape. South African Forestry Journal 189:113-117.

Holmes, P. M., D. M. Richardson, B. W. Van Wilgen, and C. Gelderblom. 2000. Recovery of South African fynbos vegetation following alien woody plant clearing and fire: Implications for restoration. Australian Ecology 25:631639.

Hulbert, L. C. 1969. Fire and litter effects in undisturbed bluestem prairie in Kansas. Ecology 50:874-877.

Joy, D. A.and D. R. Young. 2002.

Promotion of mid-successional seedling recruitment and establishment by

Juniperus virginiana in a costal environment. Plant Ecology 160:125-135.

Kush, J. S., R. S. Meldahl, and W. D. Boyer. 1999. Understory plant community response after 23 years of hardwood control treatments in natural longleaf pine (Pinus palustris) forests. Canadian Journal of Forest Resources 29:1047-1054.

Legendre, P. and L. Legendre. 1998. Numerical Ecology. Elsevier, Amsterdam. Linneman J. S. and M. W. Palmer. 2006. The effect of Juniperus virginiana L. on plant species composition in an Oklahoma grassland. Community Ecology 7: 235-244.

Limb, R. F., D. M. Engle, A. L. Alford, and E. C. Hellgren. 2010. Tallgrass prairie plant community dynamics along a canopy cover gradient of eastern redcedar (Juniperus virginiana L.). Rangeland Ecology Managment 63: 638-644.

Monk, C. D. and F. C. Gabrielson. 1985. Effects of shade, litter and root competition on old-field vegetation in South Carolina. Bulletin of the Torrey Botanical Club 112:383-392.

Palmer, M. W., D. B. Clark, and D. A. Clark. 2000. Is the number of tree species in small tropical forest plots nonrandom? Community Ecology 1:95-101.
Peltzer, D. A. and M. Köchy. 2001. Competitive effects of grasses and woody plants in mixed-grass prairie. Journal of Ecology 89:519-527.

Petranka, J. W. and J. K. McPherson. 1979. The role of Rhus copallina in the dynamics of the forest-prairie ecotone in north-central Oklahoma. Ecology 60:956965.

Provencher, L., B. J. Herring, D. R. Gordon, H. L., Rodgers, G. W. Tanner, L. A. Brennan and J. L. Hardesty. 2000. Restoration of northwest Florida sandhills through harvest of invasive Pinus clausa. Restoration Ecology 8:175-185.

Provencher, L., B. J. Herring, D. R. Gordon, H. L., Rodgers, G. W. Tanner, L. A. Brennan and J. L. Hardesty. 2001. Effects of hardwood reduction techniques on longleaf pine sandhill vegetation in northwest Florida. Restoration Ecology 9:13-27.

Schmidt, T. L. and E. C. Leatherberry. 1995. Expansion of eastern redcedar in the lower midwest. Northern Journal of Applied Forestry 12: 180-183.

Smith, S. D. and J. Stubbendieck. 1990. Production of tall grass prairie herbs below eastern redcedar. Prairie Naturalist 22:13-18.

ter Braak, C. J. F. and P. Šmilauer. 2002. Canoco for Windows 4.5. Biometris-Plant Research International. Wageningen, Netherlands.

USDA, NRCS. 2004. The PLANTS

Database, Version 3.5 (http://plants.usda.gov). National Plant Data Center, Baton Rouge, LA.

van Els, P., R. E. Will, M. W. Palmer, and K. R. Hickman. 2010. Changes in forest understory associated with Juniperus encroachment in Oklahoma, USA. Applied Vegetation Science 13:356-368.

Weaver, J. E. and N. W. Rowland. 1952. Effect of excessive natural mulch on the development, yield, and structure of a native grassland. Botanical Gazette 114:1 19. 
Whiteman, G. and J. R. Brown. 1998.

Assessment of a method for mapping woody plant density in a grassland.

Journal of Arid Environments 38:269-282.
Yager, L. Y.and F. E. Smeins. 1999. Ashe juniper (Juniperus ashei: Cupressaceae) canopy and litter effects on understory vegetation in a juniper-oak savanna. Southwestern Naturalist 44:6-16.

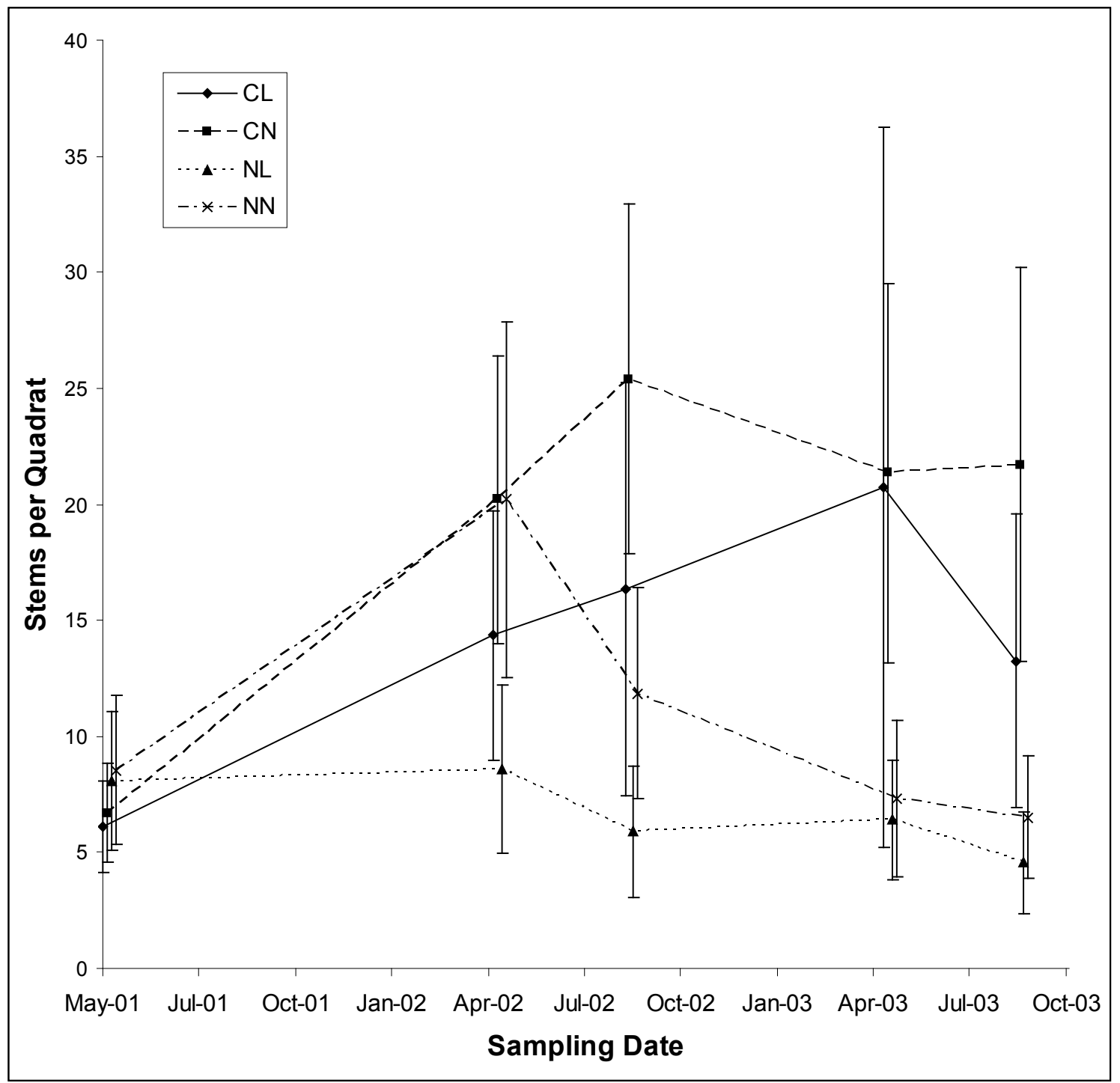

Figure 1 Mean stems per $0.25 \mathrm{~m}^{2}$ quadrat in tree removal and litter removal treatments for 2.5 years. The data points have been staggered to increase visibility of $95 \%$ confidence intervals (determined for each treatment at each sampling). $\mathrm{CL}=$ cut with-litter, $\mathrm{CN}=$ cut with no litter, $\mathrm{NL}=$ no cut with litter, $\mathrm{NN}=$ no cut with no litter. 


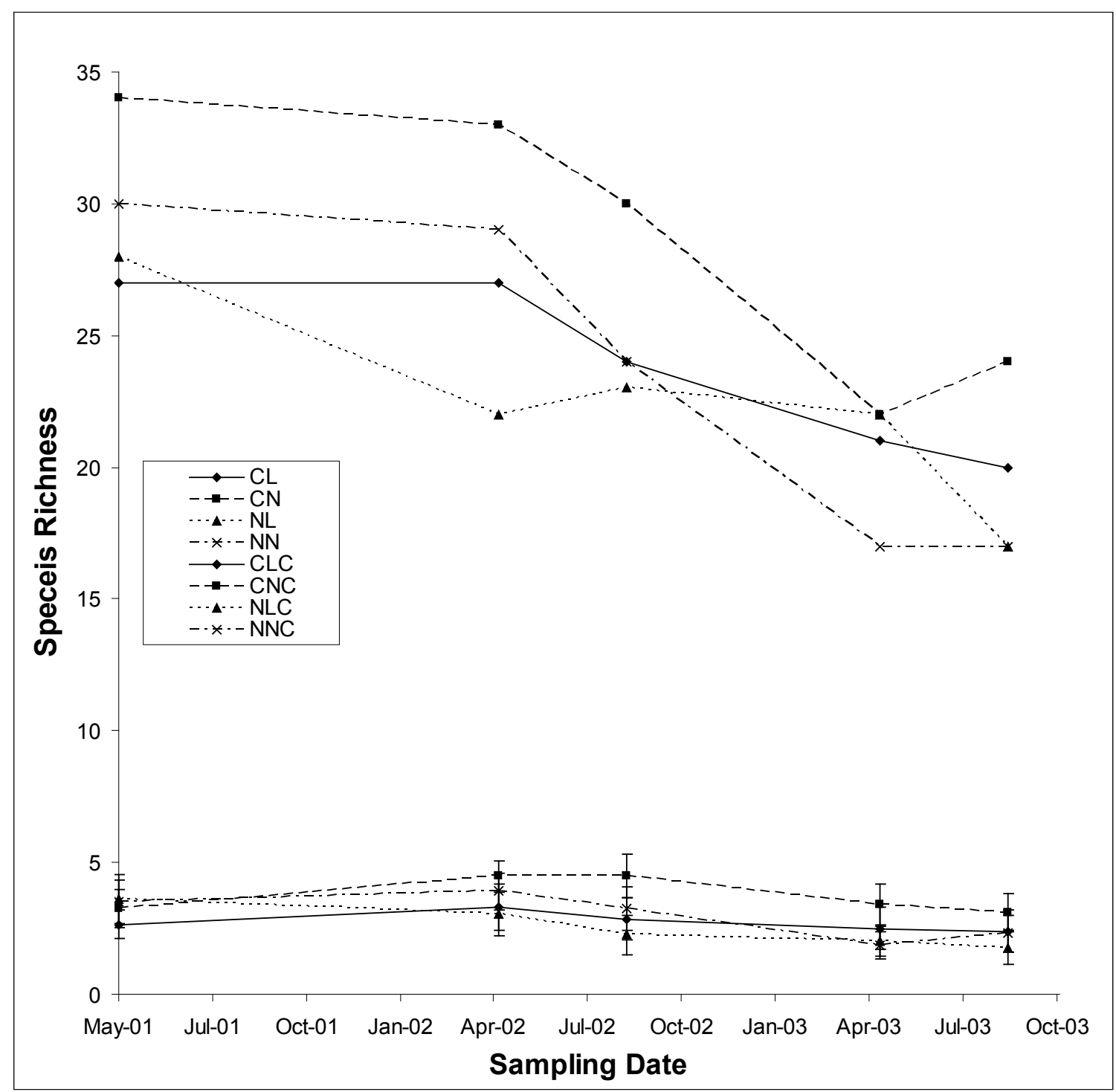

Figure 2 Mean species richness per $0.25 \mathrm{~m}^{2}$ and cumulative species richness of tree removal and litter removal treatments for 2.5 years. The data points have been staggered to increase visibility of $95 \%$ confidence intervals (determined for each treatment at each sampling). $\mathrm{CL}=$ cut with litter, $\mathrm{CLC}=$ cumulative cut with litter, $\mathrm{CN}=$ cut with no litter, $\mathrm{CNC}=$ cumulative cut with no litter, $\mathrm{NL}=$ no cut with litter, $\mathrm{CNL}=$ cumulative no cut with litter, $\mathrm{NN}=$ no cut with no litter, $\mathrm{CNN}=$ cumulative no cut with no litter of tree removal and litter removal treatments for 2.5 years. 


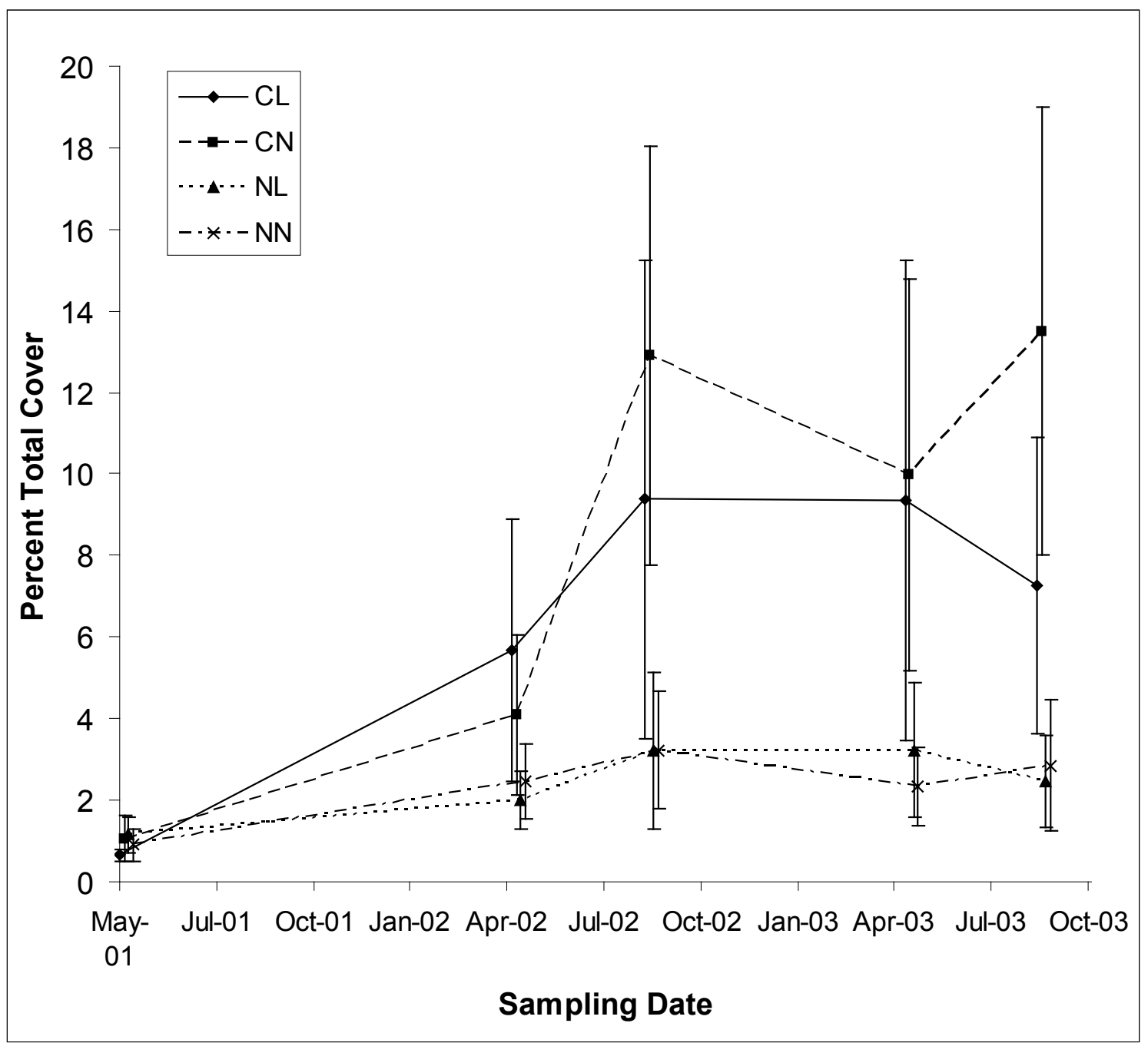

Figure 3 Mean percent total cover of tree removal and litter removal treatments for 2.5 years. The data points have been staggered to increase visibility of $95 \%$ confidence intervals (determined for each treatment at each sampling). $\mathrm{CL}=$ cut with litter, $\mathrm{CN}=$ cut with no litter, $\mathrm{NL}=$ no cut with litter, $\mathrm{NN}=$ no cut with no litter. 


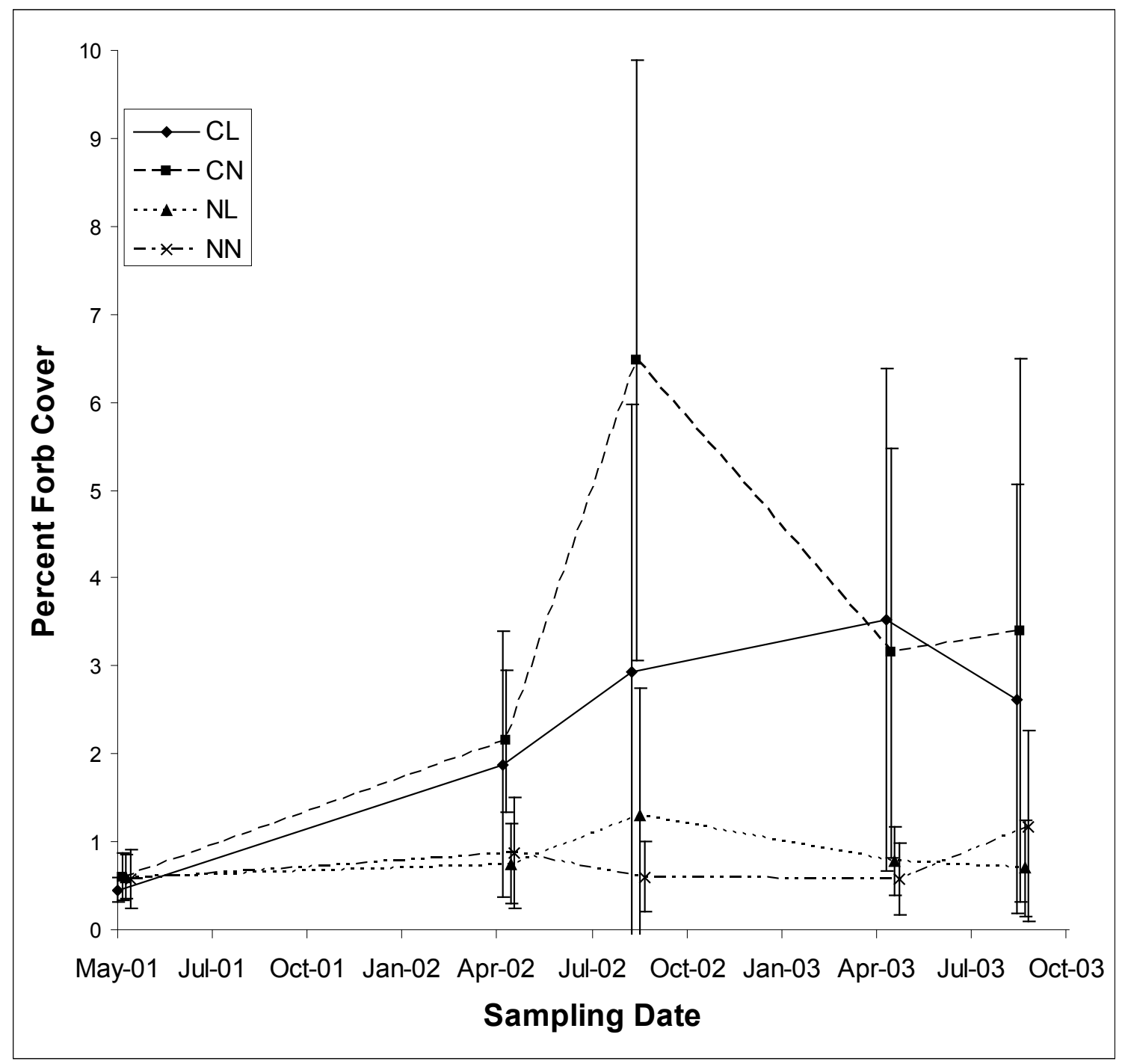

Figure 4 Mean percent forb cover of tree removal and litter removal treatments for 2.5 years. The data points have been staggered to increase visibility of $95 \%$ confidence intervals (determined for each treatment at each sampling). $\mathrm{CL}=$ cut with litter, $\mathrm{CN}=$ cut with no litter, $\mathrm{NL}=$ no cut with litter, $\mathrm{NN}=$ no cut with no litter. 


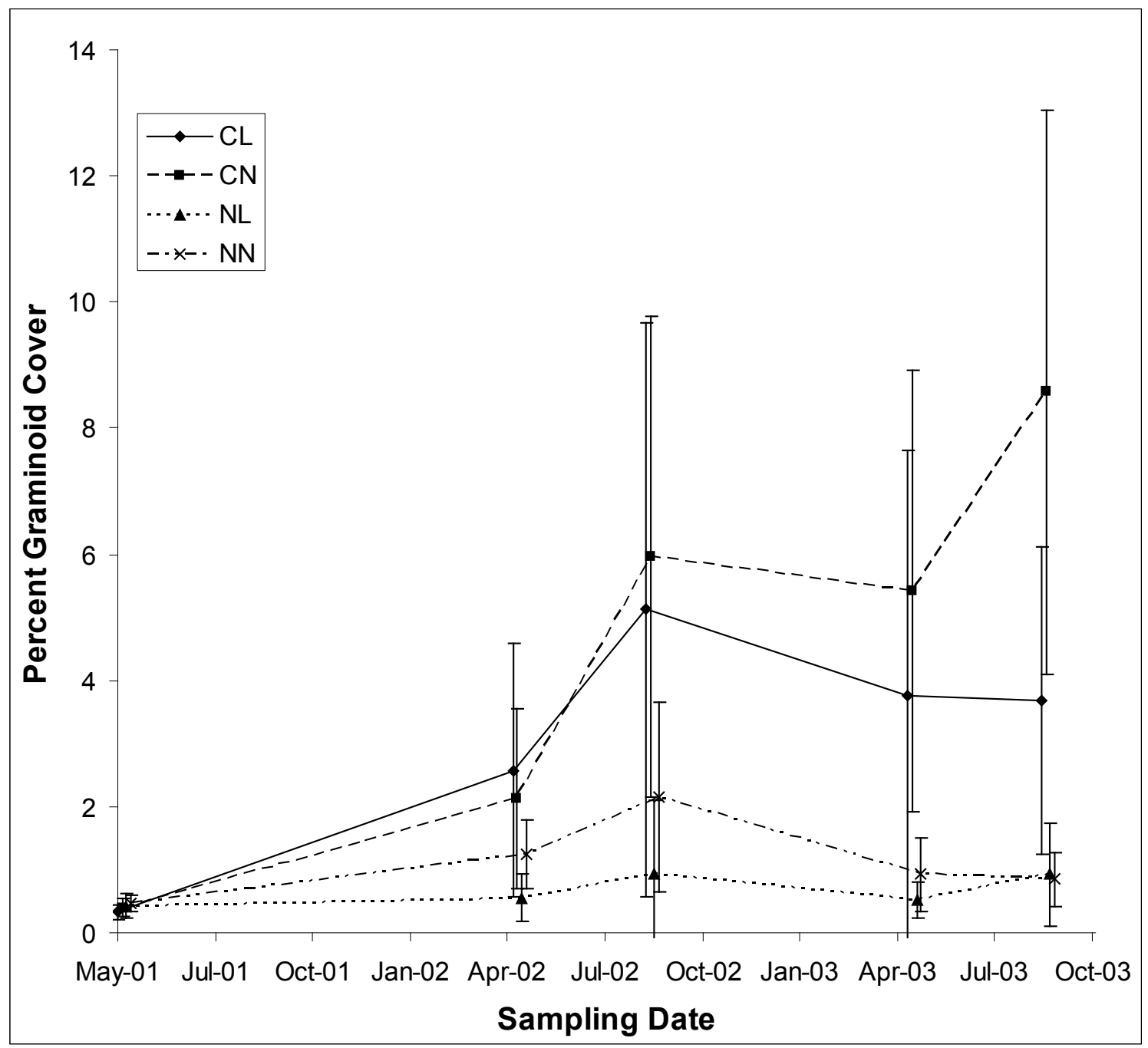

Figure 5 Mean percent graminoid cover of tree removal and litter removal treatments for 2.5 years. The data points have been staggered to increase visibility of $95 \%$ confidence intervals (determined for each treatment at each sampling). $\mathrm{CL}=$ cut with litter, $\mathrm{CN}=$ cut with no litter, $\mathrm{NL}=$ no cut with litter, $\mathrm{NN}=$ no cut with no litter. 


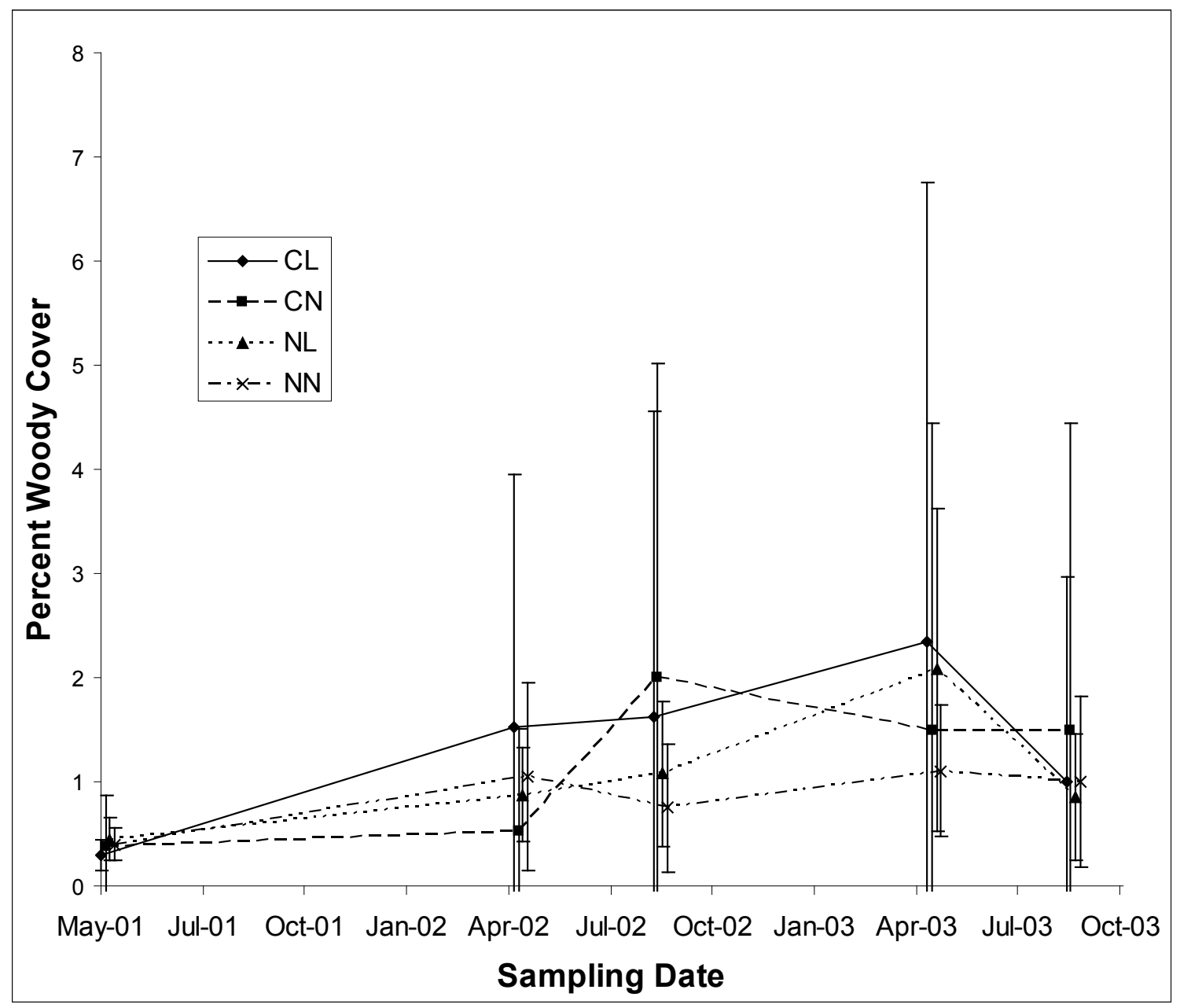

Figure 6 Mean percent woody cover of tree removal and litter removal treatments for 2.5 years. The data points have been staggered to increase visibility of $95 \%$ confidence intervals (determined for each treatment at each sampling). $\mathrm{CL}=$ cut with litter, $\mathrm{CN}=$ cut with no litter, $\mathrm{NL}=$ no cut with litter, $\mathrm{NN}=$ no cut with no litter. 

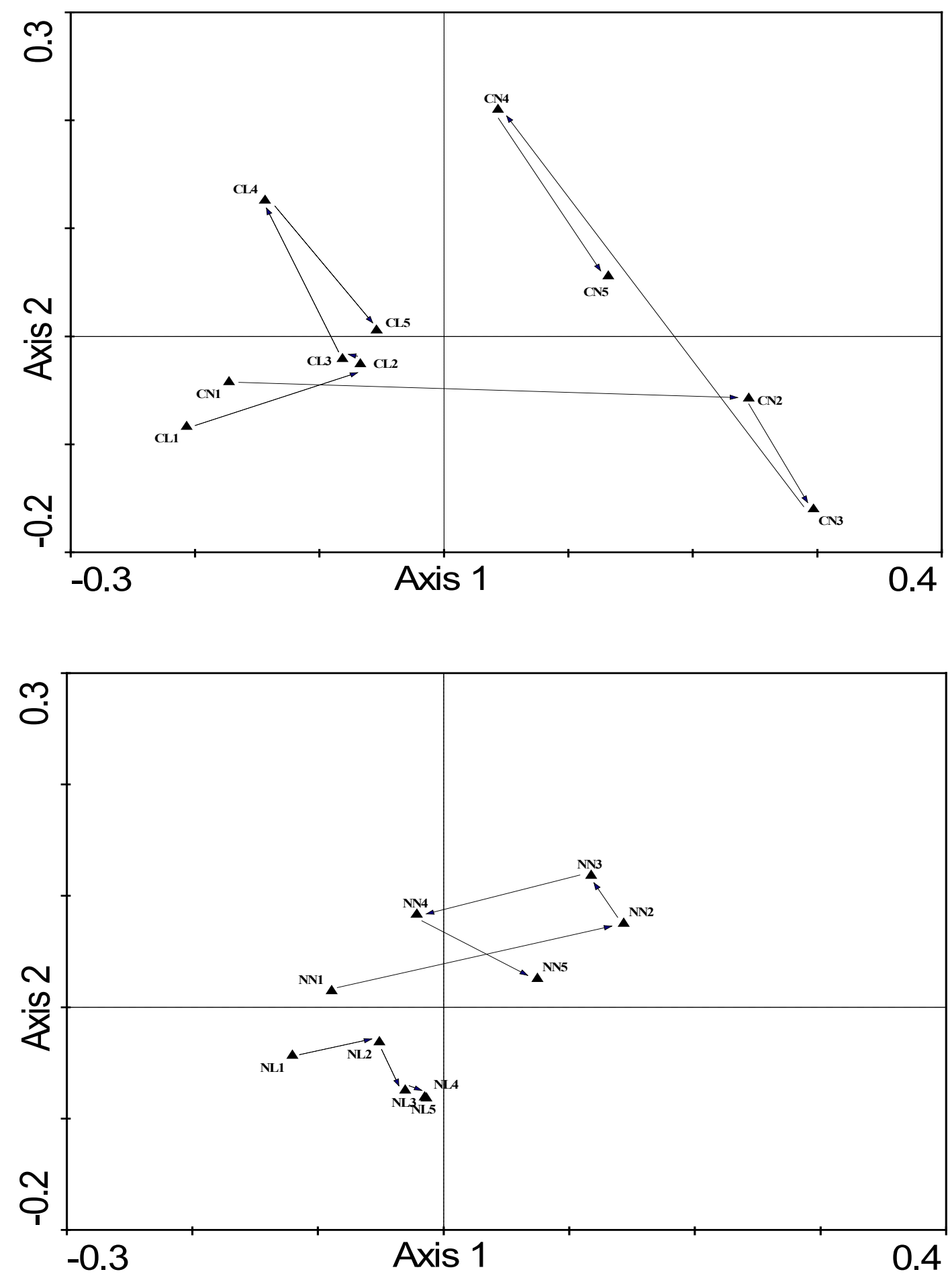

Figure 7 pRDA trajectory of tree and litter removal treatment centroids for each sampling period. The two figures are from the same analysis but were separated to increase legibility. $\mathrm{CL}=$ cut with litter, $\mathrm{CN}=$ cut with no litter, $\mathrm{NL}=$ no cut with litter, $\mathrm{NN}=$ no cut with no litter. Axes 1 and 2 are displayed in both figures. 


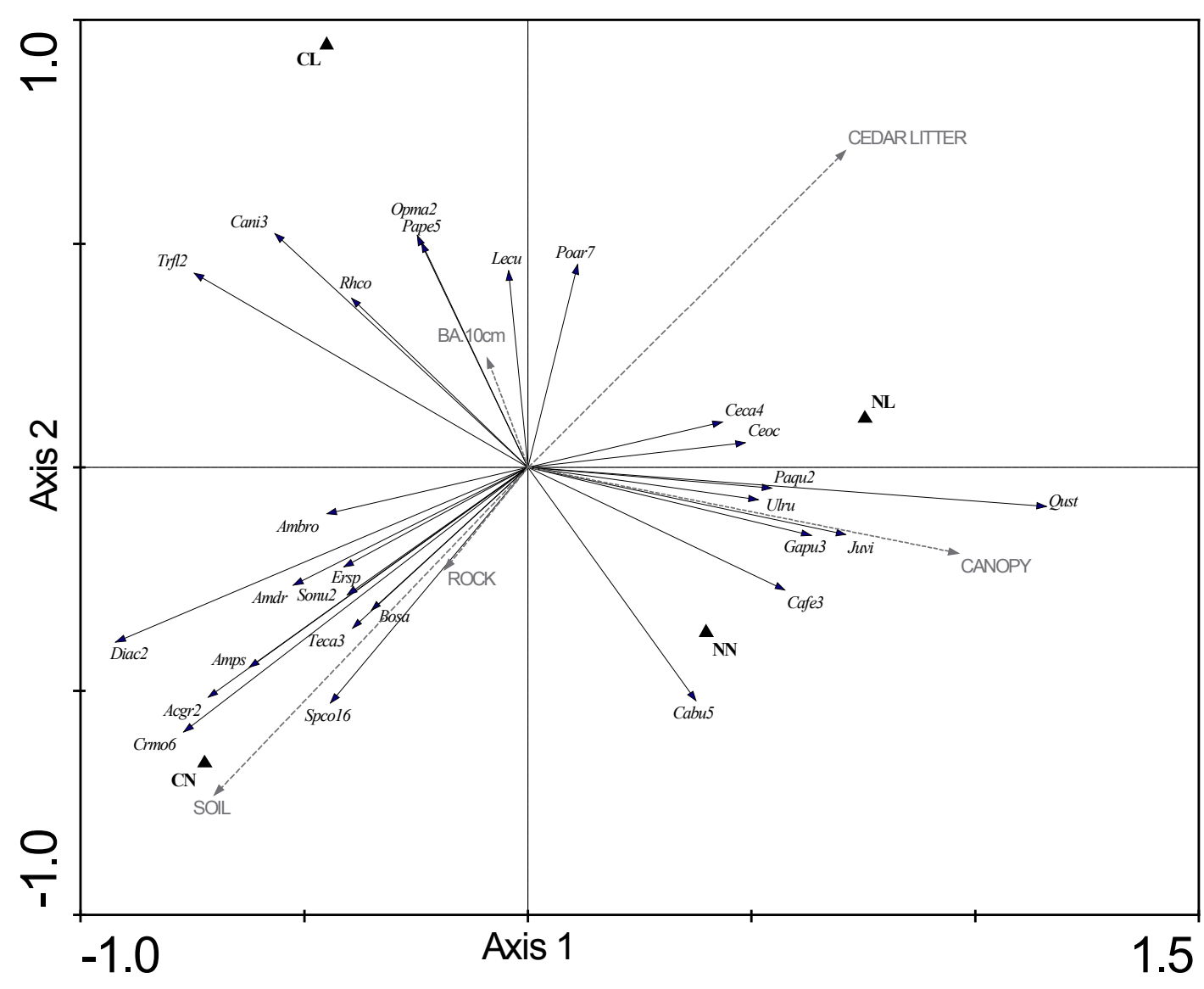

Figure 8 pRDA triplot of species codes, treatment centroids and supplemental environmental variables. All post-treatment samplings are included and axes 1 and 2 are displayed. Species codes represent the relative multi-dimensional position of each species in ordination space based on absolute cover of each species. Species codes are indexed in Appendix 1. Arrow length indicates the relative strength of supplemental variables. $\mathrm{CL}=$ cut with litter, $\mathrm{CN}=$ cut with no litter, $\mathrm{NL}=$ no cut with litter, $\mathrm{NN}=$ no cut with no litter. 


\section{APPENDIX}

Species names and USDA PLANT codes

\begin{tabular}{ll} 
Species & USDA Cod \\
Acalypha gracilens & Acgr2 \\
Ambrosia psilostachya & Amps \\
Ambrosia sp. & Ambro \\
Amphiachyris dracunculoides & Amdr \\
Bothriochloa saccharoides & Bosa \\
Carex bushii & Cabu5 \\
Carex festucacea & Cafe3 \\
Carex nigromarginata & Cani3 \\
Celtis occidentalis & Ceoc \\
Cercis canadensis & Ceca4 \\
Croton monanthogynus & Crmo6 \\
Dichanthelium acuminatum & Diac2 \\
Eragrostis spectabilis & Ersp \\
Gamochaeta purpurea & Gapu3 \\
Juniperus virginiana & Juvi \\
Lespedeza cuneata & Lecu \\
Opuntia macrorhiza & Opma2 \\
Oxalis stricta & Oxst \\
Parietaria pensylvanica & Pase5 \\
Parthenocissus quinquefolia & Paqu2 \\
Quercus stellata & Qust \\
Rhus copallinum & Rhco \\
Sorghastrum nutans & Sonu2 \\
Teucrium canadense & Spco16 \\
Tridens flavus & Teca3 \\
Ulmus rubra & Trfl2 \\
\hline Alus compositus &
\end{tabular}

Linneman, J. S., et al. 